295. CR201によるX 線グリッドの評価

国立がんセンター 放射線診断部

Q 野烟 阿南充洋

(Mi tsuhi ro Anan)

\title{
( 目的)
}

X線グリッドの物理的評価方法には，JIS規格試験 Z-4910に規定している，測定器に營光量計 を使用し全 X線透過率，一次 X線透過率及び，散乱 X線透過率より露出倍数(B)，コントラスト改善度 (K)及び，選択度(Z)を求め，その值でX線グリッドを評価する方法。なをは，X線スペクトロメータに よりそのスペクトルの解析からX線グリッドを評価する方法がある。ところが，てれらの評価方法に は問題点がある。例えば, JIS規格試験の場合，その評価は数值であるため抽象的で中々とらえにく ら面があるし，またす一つのX線スぺクトルでの評価は具体的ではあるが，その測定器及び，測定 法が煩雑で一般的ではない。

そてで今回，もら一つのグリッド評価方法として，年々增々その使用が盛んとなってきている C $\mathrm{R}$ 201 システムを用い, Imaging Plate から採取される画像の生データよりProfile. Latitude特 飞 Histgramを求め, 解析しX線グリッドの物理的評価も試みたので報告する。

( 方 法)

Profile. Latitude 及び，Histogramを求めるために Burger's Phantomを上下 $5 \mathrm{~cm}$ るクリルで挾 み込み, 撮影する。尚, Imaging Plateからのデータ収録は細かな解析がでをる様，ダイナミックレ

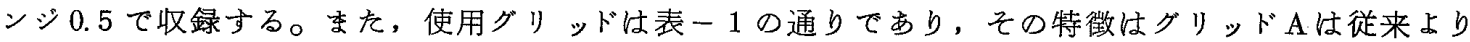
使用されている中密度グリッド，B，C壮最近良く使用されている高密度グリッドで特に，グリッド $\mathrm{C}$ は鉊䈃の厚さ及びグリッドの厚さを中密度程度とした改良型である。尚, 表右端 K はコントラスト

\begin{tabular}{c|ccccc} 
& Grid & & & \\
A & 100 & 10 & 28 & 60 & 3.6 \\
B & 100 & 10 & 50 & 30 & 3.0 \\
C & 100 & 15 & 50 & 50 & 4.4 \\
& & & & & $100 k \mathrm{~V}$
\end{tabular}

(結 果・考 察)

改善度

$f i g-1, f i g-2$ 結果を示す。JIS規格試験による物理的評 価の高レグリッドA，Cの方がHistogramの谷が深く, Burgers Phantonの穴の部分とそうでない部分とを良く認識しており， コントラストのある画像を期待できる。また，グリッド A， C の方が幅広いHi stogram となっている。Burger's Phantomの

Histogram は 2 ケ所にピークが存在する ( fig-3)。とのピーク

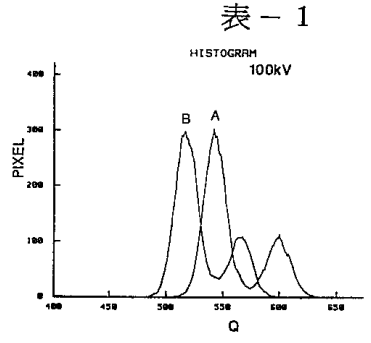

fig -1

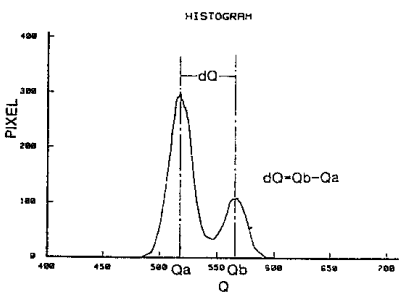

fig -3

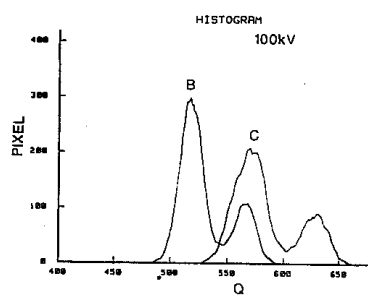

fig -2

( 結 論)

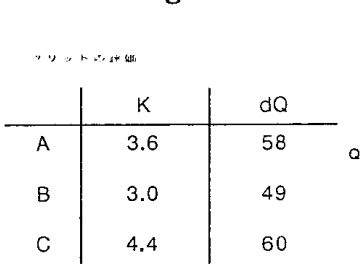

表 -2 シス量の差 $\mathrm{dQ}=\mathrm{Qb}-\mathrm{Qa}$ 公X線画像上のコント ドの物理的評価とするととが可能であり，との ことは，表一 2 亿示すJIS 規格のコントラスト 改善度 $\mathrm{K} と こ の \mathrm{dQ} の$ 值が対応していることから でわかる。次に，fig-4に各グリッドを使用 して撮影した Burger's PhantomのProfileを示 す。Non-Gridでは殆ど認識できないBurger's PhantomがJIS規格及び，C Rシステムでの物理

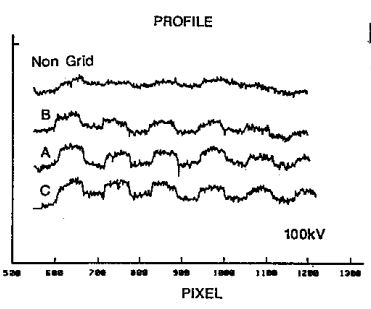

fig -4 的評価の高いグリッド(C) が Burger's Phantom を良く認識したProfile lineを示している。 Profileの観察は, Hi s togram の解析同様, グリッドの重要な評価

C Rシステムを使ったX線グリッドの評価は，JIS規格の評価と対応し有効である。特に，画像生デ 一タから求められる His togram. Profileの解析は具体的で判り易く, その試験方法る簡便である。 